\title{
The Political Economy of Exchange Rates
}

\section{Citation}

Frieden, Jeffry, and Lawrence Broz. 2006. "The Political Economy of Exchange Rates." In Oxford Handbook of Political Economy, ed. Barry Weingast and Donald Wittman, 587-600. Oxford: Oxford University Press.

\section{Published Version}

doi:10.1093/oxfordhb/9780199548477.003.0032

\section{Permanent link}

http://nrs.harvard.edu/urn-3:HUL.InstRepos:33491210

\section{Terms of Use}

This article was downloaded from Harvard University's DASH repository, and is made available under the terms and conditions applicable to Other Posted Material, as set forth at http:// nrs.harvard.edu/urn-3:HUL.InstRepos:dash.current.terms-of-use\#LAA

\section{Share Your Story}

The Harvard community has made this article openly available.

Please share how this access benefits you. Submit a story.

Accessibility 
C H A P T E R 32

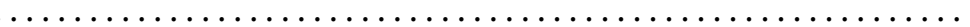 \\ THE POLITICAL ECONOMY OF EXCHANGE RATES
}

\author{
J. LAWRENCE B ROZ \\ JEFFRY A. FRIEDEN
}

THE exchange rate is the most important price in any economy, for it affects all other prices. In most countries, policy toward the national currency is prominent and controversial. Economic epochs are often characterized by the prevailing exchange rate system - the Gold Standard Era, the Bretton Woods Era. Contemporary developments, from the creation of an Economic and Monetary Union in Europe to successive waves of currency crises, reinforce the centrality of exchange rates to economic trends.

The analysis of the political economy of currency policy has focused on two sets of questions. The first is global, and has to do with the character of the international monetary system. The second is national, and has to do with the policy of particular governments towards their exchange rates. These two interact. National policies, especially of large countries, have an impact on the international monetary system. By the same token, the global monetary regime influences national policy choice.

At the frontiers of research, political economists are grappling with the complexities of this interaction, analyzing the linkages between the international and domestic aspects of exchange rate policy-making. In this essay, we start by separating the analysis of the international monetary system from the analysis of the policy choices of national governments. This allows us to simplify the issues in each area and present them in generic political economy terms. We then discuss how the issues might be analyzed jointly, across the domains, in the next phase of research. 


\section{The International Political Economy of Exchange Rate Policy}

International monetary regimes tend toward one of two ideal types. The first is a fixed rate system, in which currencies are tied to each other at publicly announced rates. Some fixed rate systems involve a common link to a commodity such as gold or silver; others peg to a national currency such as the US dollar. The second idealtypical monetary regime is free floating, in which national currency values vary with market conditions and national macroeconomic policies. There are many potential gradations between these extremes.

In the past 150 years, the world has experienced three broad international monetary orders. For about fifty years before the First World War, and again in modified form in the 1920s, most of the world was on the classical gold standard, a quintessential fixed rate system. Under the gold standard, governments committed to exchange gold for currency at an announced rate. From the late 1940s until the early 1970s, the capitalist world was organized into the Bretton Woods monetary order, a modified fixed rate system. Under Bretton Woods, currencies were fixed or 'pegged' to the US dollar and the US dollar was fixed to gold. However, national governments could change their exchange rates when they deemed it necessary. Under this 'adjustable peg' system, currencies were not as firmly fixed as under the classical gold standard. Since 1973 the reigning order has been one in which the largest countries have had floating national currencies, while smaller countries have tended either to fix their currencies against one of the major currencies or to allow their currencies to float with varying degrees of government management.

Monetary regimes can be regional as well as global. Within the international monetary free-for-all that has prevailed since 1973, a number of regional fixed rate systems have emerged. Some countries have fixed their currency to that of a larger nation: the franc zone of the African Financial Community, or 'CFA franc zone,' ties the currencies of fourteen African countries to each other and to the French franc (now to the euro). Several countries in Latin America and the Caribbean have pegged their exchange rates to the US dollar. European monetary integration began with a limited regional agreement, evolved into a Deutschmark link, and eventually became a monetary union with a single currency and a common central bank. Countries in the eastern Caribbean and southern Africa have also developed monetary unions.

Analyses of international monetary regimes treat nation-states as decision-making units (like 'firms' in microeconomics) and consider how these units deal with standard coordination and cooperation problems. Coordination entails interaction among governments to converge on a focal point-for example, linking national currencies to gold or to the dollar. This implies the existence of a Pareto improving equilibrium (often more than one), such as is the case in an assurance game, in which each actor wants to choose the same strategy as other actors. In this case, each country wants to choose the same currency regime as other countries-nobody wants to be the 
only country on gold, or the only country to float-but may disagree over which one to choose. Cooperation among nation-states involves the adjustment of national policies to support the regime-such as joint intervention in currency markets. This implies the existence of a Pareto inferior Nash equilibrium, which can be improved upon (i.e. to a Nash bargaining solution), such as is the case in a prisoner's dilemma game: countries can work together to improve their collective and individual welfare. The two problems are not mutually exclusive; indeed, the resolution of one usually presupposes the resolution of the other. But for purposes of analysis it is helpful to separate the idea of a fixed rate system as a focal point, for example, from the idea that its sustainability requires deliberately cooperative policies.

Coordination in international monetary relations. An international or regional fixed rate regime, such as the gold standard or the European Monetary System, has important characteristics of a focal point around which national choices can be coordinated (Meissner 2002; Frieden 1993). Such a fixed rate system can be self-reinforcing: the more countries that were on gold, or pegged to the Deutschmark, the greater the benefits to other countries of also choosing to go along. This can be true even if the motivations of countries differ: one might particularly appreciate the monetary stability of a fixed rate, the other the reduction in currency volatility. It does not matter, so long as the attractions of the regime increase with its membership (Broz 1997).

Most fixed rate regimes appear to grow in this way, as additional membership attracts ever more members. This was the case of the pre-1914 gold standard, which owed its start to gold-standard Britain's centrality to the nineteenth-century international economy, and its eventual global reach to the accession of other nations to the British-led system. European monetary integration also progressed in this manner, as the Deutschmark zone of Germany, Benelux, and Austria gradually attracted more European members. The focal nature of a fixed rate system can lead to a 'virtuous circle' as more and more countries sign on, but the unraveling of the regime can lead to a 'vicious circle.' The departure of important countries from the system can reduce its centripetal pull, as with the collapse of the gold standard in the 1930s: British exit began a stampede which led virtually the rest of the world off gold within a couple of years.

We have illustrated coordination problems by reference to fixed rate regimes, but similar problems arise in floating rate regimes. Members of a floating regime can benefit-individually and jointly-by committing to a common standard on payments and exchange restrictions (Simmons 2000). A focal point in this respect is the voluntary standard on payments restrictions embodied in the International Monetary Fund's Articles of Agreement. The IMF standard proscribes governments from rationing or limiting access to foreign exchange when citizens request it to pay for imports or service a foreign debt. This promotes international trade, which benefits all members. Simmons (2000) finds strong evidence of regional diffusion effects, suggesting that the gains of adopting the standard increase with the number of nations in a region that do so. 
Cooperation in international monetary relations. International monetary relations may require the resolution of problems of cooperation. A fixed rate system may give governments incentives to 'cheat,' such as to devalue for competitive purposes while taking advantage of other countries' commitment to currency stability. Even a system as simple as the gold standard sometimes relied on agreements among countries to support each others' monetary authorities in times of difficulty. An enduring monetary system, in this view, requires explicit cooperation among its principal members.

The welfare gains associated with interstate collaboration in the international monetary realm are several. First, reduced currency volatility almost certainly increases international trade and investment. Second, fixed rates tend to stabilize domestic monetary conditions, so that international monetary stability reinforces domestic monetary stability. Third, predictable currency values can reduce trade conflicts: a rapid change in currency values often leads to an import surge, protectionist pressures, and commercial antagonism.

These joint gains may be difficult to realize because they can require national sacrifices. Supporting the fixed rate system may require painful adjustment policies to sustain a country's commitment to its exchange rate. Governments may be forced to raise interest rates to high levels in order to defend an overvalued currency, and the domestic economic and political consequences can lead to conflict over the international distribution of adjustment costs. For example, under Bretton Woods and the European Monetary System, one country's currency served as the system's anchor. This forced other countries to adapt their monetary policies to the anchor country, and led to pressures on the key-currency government to bring its policy more in line with conditions elsewhere. Under Bretton Woods, from the late 1960 until the system collapsed, European governments wanted the United States to implement more restrictive policies to bring down American inflation, while the US government refused. In the EMS in the early 1990s, governments in the rest of the European Union wanted Germany to implement less restrictive policies to combat the European recession, while the German central bank refused. Generally speaking, the better able countries are to agree about the distribution of the costs of adjustment, the more likely they are to be able to create and sustain a common fixed rate regime.

Historically, intergovernmental cooperation has been crucial to the durability of fixed rate monetary systems. Barry Eichengreen (1992) argues that credible cooperation among the major powers before 1914 was the cornerstone of the classical gold standard, while its absence explains the inter-war failure to revive the regime. Many regional monetary unions, too, seem to obey this logic: where political and other factors have encouraged cooperative behavior to safeguard the common commitment to fixed exchange rates, the systems have endured, but in the absence of these cooperative motives, they have decayed (Cohen 2001).

Two recent regional ventures, Economic and Monetary Union in Europe (EMU) and dollarization in Latin America, illustrate these international factors. Dollarization appears largely to raise coordination issues, as national governments consider independent choices to adopt the US dollar. The principal attraction for dollarizers is association with dollar-based capital and goods markets; the more countries dollarize, 
the greater this attraction will be. The course of EMU from 1973 to completion did have features of a focal point, especially in the operation of the European Monetary System as a Deutschmark bloc, but the transition to EMU went far beyond this. Participants bargained over the structure of the new European Central Bank, the national macroeconomic policies necessary for membership in the monetary union, and a host of other issues. These difficult bargains were unquestionably made much easier by the small number of central players, the institutionalized EU environment, and the network of policy linkages between EMU and other European initiatives.

Despite the importance of international factors, international monetary cooperation and coordination rest on the foundation of national currency policies, which are subject to an array of political economy pressures.

\section{The Domestic Political Economy of Exchange Rate Policy}

Political factors within nations give rise to two basic types of pressures for-or against - coordination and cooperation in the international arena. On the one hand, exchange rate policies involve trade-offs with domestic distributional implications. International coordination or cooperation may not find sufficient support within a nation, if the losers are sufficiently powerful. On the other hand, exchange rate policies have electoral implications. The exchange rate is such an important price that politicians may wish to manipulate it for the purpose of winning elections, rather than stabilizing an international regime. We suggest ways in which distributional politics and electoral politics might interact with external monetary conditions to shape exchange rate outcomes.

Two fundamental currency decisions confront policy-makers, and each has distributional consequences. First, policy-makers must decide whether to heed external signals and join the dominant international or regional regime. This regime decision involves choosing whether to allow the currency to float freely, to be fixed against some other currency, or to adopt a system in between a hard fix and a pure float. Second, for all but irrevocably fixed rate regimes, policy-makers also confront choices involving the level of the exchange rate, the price at which the national currency trades in foreign exchange markets. Level decisions fall along a second continuum that runs from a more depreciated to a more appreciated currency. Although regime and level decisions are interconnected, we treat them separately to illustrate their distinct political economy implications.

Choice of exchange rate regime. Regime decisions involve trade-offs among desired national goals, whose benefits and costs fall unevenly on actors within countries. Fixed rate regimes have two main national benefits. First, they promote trade and investment by reducing exchange rate risk. Countries that share a common currency 
or have a long-term peg appear to trade much more than comparable countries with separate currencies (Rose 2000). Second, fixed rates promote domestic monetary stability. By anchoring the value of the domestic currency to a low-inflation currency (or gold), monetary officials are constrained to follow a time-consistent path of low inflation (Giavazzi and Pagano 1988; Canavan and Tommasi 1997). The cost of fixing is the flip side of this benefit: forfeiture of domestic monetary policy independence. When local monetary conditions cannot differ from conditions in the anchor country, monetary policy cannot be used for domestic macroeconomic stabilization.

The distributional effects of regime choice follow from these aggregate costs and benefits: groups involved in foreign trade and investment (international banks and investors, exporters) should favor fixed rate systems because exchange rate stability promotes trade and investment (Frieden 1991). By contrast, groups whose economic activity is limited to the domestic economy (non-tradeables producers, importcompeting sectors) should prefer a floating regime that allows the government to stabilize domestic economic conditions.

Scholars have examined the role of interest groups in exchange rate regime determination in a variety of contexts, from the historical gold standard to contemporary currency politics in Europe and Latin America. Many have found that interest groups line up as anticipated, and that they seem to have an impact on policy outcomes (Hefeker 1995; Eichengreen 1995; Frieden 1997; Frieden, Ghezzi, and Stein 2001; Frieden 2002). However, research on the role of distributionally motivated interest groups in currency relations is not well developed. The determinants of interest group preferences require more detailed analysis, to specify more precisely how economic characteristics of firms and industries relate to their exchange rate preferences. More attention also needs to be paid to organizational characteristics of such interest groups, to show how their features relate to their ability to engage in collective political action.

In many instances, interest group preferences are relevant inasmuch as they are mediated through political parties (Bearce 2003). Some have argued that centrist and rightist parties are likely to support fixed regimes as their business constituencies benefit from the credible commitment to low inflation, and from the expansion of trade and investment made possible by fixing (Simmons 1994). Left-wing parties, by contrast, favor flexible regimes since labor bears the brunt of adjusting the domestic economy to external conditions. However, the character of partisan influences on exchange rate policy is not straightforward and further analysis will need to clarify their operation, and how they, in turn, relate to differences in electoral and legislative institutions.

Another suggestion for future work is to give more attention to how international regime conditions affect domestic lobbying. For example, an implication of the focal point interpretation of international regimes is that interest group pressures might be the mechanism by which nations coordinate on a certain international regime, as suggested by Frieden (1993) and Broz (1997). In this account, the reason why the attraction of joining an international regime increases with the number of members is that interest group lobbying intensifies with the growth of a regime. Researchers have 
also recognized that regime choice has electoral implications, which vary with the structure of political institutions (Bernhard and Leblang 1999). It is easy to envision scenarios in which an office-seeking politician would be loath to join a fixed-rate international regime, as it would mean depriving himself of a tool to influence the economy for electoral purposes. In countries where the stakes in elections are high (e.g. single-member plurality systems), politicians may prefer a floating regime as a means to preserve the use of monetary policy to engineer greater support before elections. Where elections are not as decisive (e.g. proportional representation systems), fixing has smaller electoral costs, implying that fixed regimes are more likely to be chosen. When the timing of elections is predetermined, governing parties are less likely to surrender monetary policy by pegging, since it can be a useful tool for winning elections. When election timing is endogenous, there is less need for monetary flexibility, so pegging is more likely.

In the developing world, it may be the absence of democracy, rather than its form, that matters. One regularity is that non-democracies are more likely to adopt a fixed regime for low inflation purposes than democracies (Broz 2002; Leblang 1999). Non-democracies may peg because they are more insulated from domestic audiences, and bear lower political costs of adjusting the economy to the peg. Or they may peg because other alternatives, like central bank independence (CBI), are less viable in a closed political system. More generally, if fixed exchange rates and CBI are alternative forms of monetary commitment, then it is necessary to analyze the decision as a joint policy choice in which governments weight the costs and benefits of all alternatives (Bernhard, Broz, and Clark 2003). Analysts might pursue the idea that currency regimes and domestic monetary institutions are policy substitutes, and try to explain why some nations prefer exchange rate-based sources of low inflation credibility while others adopt domestic rules and institutions. Part of the explanation may reside outside the scope of domestic institutions and politics, in the character of the international monetary regime. At the margins, the existence of a large global or regional fixed rate regime may tip the decision toward an exchange rate-based stabilization, by adding the political economy benefits of greater trade to the extant credibility gains.

To appreciate or depreciate? As with the regime decision, the choice on the level of the exchange rate has distributional and electoral implications. Of course, governments cannot directly set the real exchange rate, but they can affect trends in the real exchange rate over a period long enough to be of political and economic significance-typically estimated at three to five years. Thus a government must decide whether it prefers a relatively appreciated or a relatively depreciated currency. This choice involves a basic political-economy trade-off between competitiveness and purchasing power.

The real exchange rate affects the relative price of domestically produced goods in local and foreign markets, and it also affects the purchasing power of those who earn the currency. A real appreciation increases the purchasing power of local residents, by lowering the relative price of foreign (more generally, tradeable) goods. However, 
by making domestic goods more expensive relative to foreign goods, it reduces the 'competitiveness' of local tradeables producers. A real depreciation has the opposite effects, reducing purchasing power but improving competitiveness by lowering the price of domestically produced goods.

There is no clear economic guideline as to the appropriate level of the exchange rate. A relatively depreciated currency encourages exports and expenditure switching from imports to domestic goods, thereby boosting aggregate output. However, depreciation can have contractionary effects that follow from higher prices. While the net effect on overall national welfare is very hard to calculate, the level of the exchange rate has clear distributive consequences domestically. Export and import competing industries lose and domestically oriented (non-tradeables) industries gain from currency appreciation (Frieden 1991). Domestic consumers/voters also gain as the domestic currency price of imported (and tradeable) goods falls, lowering the cost of living. Currency depreciations have the opposite effects, helping exporting and import competing industries at the expense of domestic consumers and non-traded industries.

Group currency preferences are affected by economic factors, and their ability to turn these preferences into policy is affected by political institutions. Economically, the distributional impact of exchange rate changes is contingent on economic characteristics of industries and firms, for example the sensitivity of product prices to currency movements. Many goods prices do not respond rapidly to changes in currency values, a phenomenon associated with the fact that foreign producers are reluctant to 'pass through' the exchange rate change to local consumers for fear of losing market share. Producers of goods with low pass-through-specialized, highly differentiated, products, such as automobiles-will be less concerned with the exchange rate than producers of goods with high pass-through, typically more standardized products. By the same token, the extent to which an industry relies on imported intermediate inputs will also determine whether it is harmed or helped by appreciation (Campa and Goldberg 1997).

A number of regularities about preferences over the currency level can be identified. These are related to points made above about regime preferences. For example, the argument that producers of simple tradeables are relatively insensitive to currency volatility complements the argument that they are very sensitive to the level of theexchange rate: producers of commodities and simple manufactures will prefer a flexible regime and a tendency for a depreciated currency. On the other hand, the argument that producers of complex and specialized tradeables are very sensitive to currency volatility complements the argument that they are relatively insensitive to the level of the exchange rate: these producers will prefer a fixed regime. Capturing an industry's (or an entire nation's) sensitivity to exchange rate changes involves measuring the extent to which it sells products to foreign markets, uses foreign-made inputs, and, more indirectly, competes with foreign manufacturers on the basis of price (Frieden, Ghezzi, and Stein 2001).

The panoply of interests in the exchange rate makes the political institutions within which they are expressed particularly important to explaining policy outcomes. 
Political institutions affect the impact of special interests on economic policy, including on exchange rate policy. By the same token, exchange rate policies are likely to be affected by varieties of electoral institutions, and by election timing. This is because the real exchange rate affects broad aggregates like purchasing power, growth rates, and the price level, and these broad aggregates are almost certainly relevant to elections. Indeed, governments tend to maintain appreciated currencies before elections, delaying a depreciation/devaluation until after the election (Klein and Marion 1997; Frieden, Ghezzi, and Stein 2001; Leblang 2002). Electoral cycles in exchange rate policy help explain some characteristics of the currency crises that have been common over the past twenty years. Although the causes of currency crises are controversial (Corsetti, Pesenti, and Roubini 1999), delaying devaluation certainly makes the problem worse. Given the political unpopularity of a devaluation-induced reduction in national purchasing power, governments may face strong incentives to avoid devaluing even when the result is a more severe crisis than would otherwise be expected. In Mexico in 1993-4 and Argentina in 1999-2001, for example, electorally motivated delays almost certainly led to far more drastic currency collapses than would have otherwise been the case. The electoral cycle is likely to be muted in countries where the central bank has sufficient insulation from political pressures, or the government has a time horizon long enough to endogenize the higher costs of delayed action on the exchange rate. Political institutions condition the extent to which politicians are willing or able to respond to short-run electoral incentives.

Interest group activity on the level of the exchange rate varies greatly over time and across country, and its impact on policy is a function of national political institutions. Analyses of the politics of exchange rate policy evaluate both special and masspolitical interests, and the institutions within which they are expressed, and have found strong evidence of interest group and election cycle effects on policy.

One research frontier is the role of exchange rate policy as a substitute for other policies (and vice versa). For example, currency policy and trade policy are close substitutes: a 10 per cent real depreciation is equivalent to a 10 per cent import tax plus a 10 per cent export subsidy. Hence, the tradeables sector can organize on an industryby-industry basis to seek trade barriers or export subsidies, or as a whole to attempt to obtain a depreciation. This requires careful consideration of the organizational, political institutional, and other factors that might lead private actors to pursue one policy or the other, and public policy-makers to use one policy or the other. Exchange rate policies are similarly closely related to policies toward capital flows, financial regulation, and many other arenas. A full analysis of the political economy of exchange rate policy requires consideration of its alternatives.

Another research challenge is to integrate the external regime environment into analyses of the domestic politics of exchange rate levels. The character of the extant regional or international exchange rate regime may condition national policy decisions on whether to appreciate or depreciate the currency. On the one hand, an external regime with explicit rules and sanctions regarding members' exchange rate policies can make it difficult for a nation pressured by weak currency interests to depreciate for competitive purposes. On the other, regime rules and monitoring mechanisms 
may limit the ability of national politicians to manipulate exchange rates for electoral purposes, especially if such manipulations impose costs on other governments.

\section{Conclusions}

Exchange rates are prominent features of economic life, and the study of their political economy is important. Scholars have made substantial progress in understanding how regional and international currency regimes emerge and evolve, and why governments pursue the exchange rate policies they do.

At the international level, the study of global and regional monetary regimes has incorporated developments in the analysis of international coordination and cooperation to explain the origin and operation of such systems over the past two centuries. At the domestic level, there is a reasonably well-developed set of arguments about the economic interests at stake, and about how political institutions affect currency policy choices.

Future research confronts several challenges. First, it needs to continue to integrate international and domestic sources of exchange rate policy. Just as national policymakers take the international regime into account when deciding how to manage their currencies, so too should our models. Second, it needs to clarify and refine the theoretical and empirical uncertainties that remain in existing scholarship. Third, in concert with scholars in other areas of political economy, it needs to incorporate the impact of such closely related issue areas as trade and financial policy on international monetary affairs. These are substantial challenges, but the past ten years have seen impressive progress in the study of exchange rate politics, and there is no reason to doubt that the coming decades will be just as fruitful.

\section{REFERENCES}

Bearce, D. 2003. Societal preferences, partisan agents, and monetary policy outcomes. International Organization, 57: 373-410.

Bernhard, W., Broz, J. L., and Clark, W. R. 2003. The Political Economy of Monetary Institutions. Cambridge, Mass.: MIT Press.

and Leblang, D. 1999. Democratic institutions and exchange-rate commitments. International Organization, 53: 71-97.

Broz, J. L. 1997. The domestic politics of international monetary order: the gold standard. Pp. 53-91 in Contested Social Orders and International Politics, ed. D. Skidmore. Nashville: Vanderbilt University Press.

2002. Political system transparency and monetary commitment regimes. International Organization, 56: 861-87.

CAmpa, J., and Goldberg, L. S. 1997. The evolving external orientation of manufacturing: a profile of four countries. Federal Reserve Bank of New York Economic Policy Review, 3: 53-70. 
Canavan, C., and Tommasi, M. 1997. On the credibility of alternative exchange rate regimes. Journal of Developmental Economics, 54: 101-22.

Cohen, B. J. 2001. Beyond EMU: the problem of sustainability. Pp. 179-204 in The Political Economy of European Monetary Unification, 2nd edn., ed. B. Eichengreen and J. Frieden. Boulder, Colo.: Westview Press.

Corsetti, G., Pesenti, P., and Roubini, N. 1999. What caused the Asian currency and financial crisis? Japan and the World Economy, 11: 305-73.

Eichengreen, B. 1992. Golden Fetters. Oxford: Oxford University Press.

1995. The endogeneity of exchange rate regimes. Pp. 3-33 in Understanding Interdependence, ed. P. Kenen. Princeton, NJ: Princeton University Press.

Frieden, J. A. 1991. Invested interests: the politics of national economic policy in a world of global finance. International Organization, 45: 425-51.

1993. The dynamics of international monetary systems: international and domestic factors in the rise, reign, and demise of the classical gold standard. Pp. 137-62 in Coping with Complexity in the International System, ed. R. Jervis and J. Snyder. Boulder, Colo.: Westview Press.

1997. Monetary populism in nineteenth-century America: an open economy interpretation. Journal of Economic History, 57: 367-95.

2002. Real sources of European currency policy: sectoral interests and European monetary integration. International Organization, 56: 831-60.

Ghezzi, P., and Stein, E. 2001. Politics and exchange rates: a cross-country approach to Latin America. Pp. 21-63 in The Currency Game: Exchange Rate Politics in Latin America, ed. J. A. Frieden and E. Stein. Baltimore: Johns Hopkins University Press.

Giavazzi, F., and Pagano, M. 1988. The advantage of tying one's hands: EMS discipline and central bank credibility. European Economic Review, 32: 1055-75.

GowA, J. 1988. Public goods and political institutions: trade and monetary policy processes in the United States. International Organization, 42: 15-32.

HefeKer, C. 1995. Interest groups, coalitions and monetary integration in the nineteenth century. Journal of European Economic History, 24: 489-536.

Klein, M. W., and Marion, N. P. 1997. Explaining the duration of exchange-rate pegs. Journal of Development Economics, 54: 387-404.

Leblang, D. 1999. Democratic political institutions and exchange rate commitments in the developing world. International Studies Quarterly, 43: 599-620.

2002. The political economy of speculative attacks in the developing world. International Studies Quarterly, 46: 69-91.

Meissner, C. M. 2002. A new world order: explaining the emergence of the classical gold standard. NBER Working Paper no. 9233 (Oct.), forthcoming, Journal of International Economics.

Rose, A. 2000. One money, one market: estimating the effect of common currencies on trade. Economic Policy, 30: 7-46.

Simmons, B. 1994. Who Adjusts? Princeton, NJ: Princeton University Press.

2000. International law and state behavior: commitment and compliance in international monetary affairs. American Political Science Review, 94: 819-35. 
